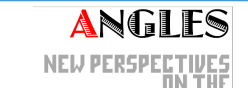
ANELOPHONE WORLD

\section{Angles}

New Perspectives on the Anglophone World

$8 \mid 2019$

Neoliberalism in the Anglophone World

\title{
Robots and Immigrants: Employment, Precarisation and the Art of Neoliberal Governance
}

\section{Kostas Maronitis}

\section{(2) OpenEdition}

1 Journals

\section{Electronic version}

URL: https://journals.openedition.org/angles/570

DOI: 10.4000/angles.570

ISSN: 2274-2042

\section{Publisher}

Société des Anglicistes de l'Enseignement Supérieur

\section{Electronic reference}

Kostas Maronitis, "Robots and Immigrants: Employment, Precarisation and the Art of Neoliberal Governance", Angles [Online], 8 | 2019, Online since 01 April 2019, connection on 06 June 2022. URL: http://journals.openedition.org/angles/570 ; DOI: https://doi.org/10.4000/angles.570

This text was automatically generated on 6 June 2022.

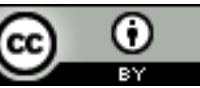

Angles est mise à disposition selon les termes de la Licence Creative Commons Attribution 4.0 International. 


\title{
Robots and Immigrants: Employment, Precarisation and the Art of Neoliberal Governance
}

\author{
Kostas Maronitis
}

1 Employment is one of the defining topics of contemporary economies and societies. Prosperity, education, equality, well-being and overall social and political progress are largely imagined through the prism of employment. Qualitative differences in employment regarding income and location constitute a powerful metric system for evaluating education, cultural capital and social mobility. Most importantly, employment has become synonymous with existential anxieties concerning social hierarchy, identity and self-worth. However, employment has never been more precarious and employees have never felt more insecure. Fixed and zero-hours contracts, low incomes and continuous corporate restructurings are permanent features of the present political and economic landscape. These features can either be justified as a means to overcome low productivity in capitalist societies or can be explained as a manifestation of dysfunctional economies.

2 Arguments about low productivity, inefficient labour force, and lack of appropriate skills in the UK labour market have generated strong socio-political responses: from enthusiasm about the implementation and economic benefits of Artificial Intelligence (AI) and automation to sectors of the economy previously immune to such technological changes, to wider scepticism about massive loss of jobs and lack of a transition period for workers to acquire new skills for a new technological capitalist environment. At the same time, Britain's insecure position within the world economy due to the result of the referendum on membership of the European Union (EU) and to the subsequent negotiations with EU officials have given rise to business demands for sustaining the current rates of immigrant labour force in the British economy. More specifically, these demands focus on the need for cheap and/or low-skilled immigrant labour in the service and agriculture sectors for a competitive and growing economy. The competitiveness of the economy and national living standards appear to be 
interdependent with an uninterrupted flow of immigrants from the EU and elsewhere, usually defined by low salaries, elastic working hours, and limited rights.

Whilst there is a growing body of research which convincingly examines the intellectual history of automation via the work of Marx (2004) and the Italian operaismo movement (Virno 2004; Berardi 2017) as well as the working conditions and rights of immigrant workers, there is very little on the ideological and political infrastructure that brings those two seemingly disparate discourses together. In this article, I argue that automation and demands for low-skilled immigrant labour are not only part of a political and economic agenda dealing exclusively with economic growth and productivity but also of a conscious attempt to produce a subject best suited to fulfil this agenda. Considering those two discourses, the article raises the following question: is there a connection between contemporary economic imaginaries of employment and productivity and specific modes of political governance?

The empirical material of this article derives, on the one hand, from economic and business reports dealing with the advent of AI and automation and its impact on productivity and employment and, on the other hand, from reports putting forward the argument that the flow of immigrant labour is integral to economic growth and prosperity. More specifically, the article will engage with relevant details from the Autumn Budget presented by the UK Government to the House of Commons in 2017; reports from PricewaterhouseCoopers (Berriman 2017); the World Economic Forum (Gray 2016); the International Transport Forum (2017); the Future of Work Commission (2017); the National Institute of Economic and Social Research (Rolfe 2016; Rolfe and Hudson-Sharpe 2016); the Royal Association of British Dairy Farmers (2017); and the National Farmers Union (2017).

5 For the purpose of avoiding a reductionist and economics-centred understanding of the discourses of technological displacement and low-skilled immigrant labour respectively, the article has to confront the socio-political devices which contribute to the detachment of the economy from politics and society and to the reification of terms and concepts such as productivity, training and competition. The analysis of the empirical material is not limited to questions over the dominant reading of reports, policies and public statements but extends to the way these discourses contribute to an all-encompassing art of neoliberal governance. This article provides an analysis of the narratives of the aforementioned reports in order to discover common themes and salient socio-political constructs. In particular, this article describes the dominant terms and themes featuring in the reports, policies and statements and then identifies the ways in which they are culturally and historically specific, and how they relate to each other; it reveals the commonalities that exist between the data, and then aims to produce generalised knowledge of neoliberalism and governance based on the selected data.

6 The article is organised as follows: the first section will focus on the meaning(s) of neoliberalism as an economic system and political logic and will establish its relationship with the state. The second and third sections will focus on the content and ideological implications of the reports and policies regarding automation of labour and low-skilled immigrant labour. The fourth section will bring the discourses of automation and low-skilled immigrant labour together under the concept of homo cconomicus and will examine their points of convergence and divergence by considering qualitative differences of precarity as an art of neoliberal governance. 


\section{The State of/in Neoliberalism}

7 Any discussion about neoliberalism as a system of political and economic organisation needs to consider the ambiguous relationship between the state and the economy. Despite its dominance as a political and economic order, neoliberalism is hard to define. As Jessop (2012) notes, neoliberalism is more often used by critics of contemporary capitalist systems than by its proponents. In fact, Jessop refers to the impossibility of talking about neoliberalism as a singular and coherent term and the need to acknowledge multiple forms and manifestations of neoliberalism. However, there exist two permanent features in neoliberalism in all its manifestations. First, it aspires to expand the mechanisms of competitive markets to all aspects of social and political life. Second, it has a problematic and occasionally hostile relationship with the state. If the state prohibits the expansion of the market and, by association, individual freedom, then its powers need to be either minimised or adjusted to new economic and political realities.

Initially, the state was seen as counterproductive or even threatening to capital accumulation and economic growth. Theoretical economist Ludwig von Mises (1998) notably equated state intervention in economic affairs with socialism and effectively with the loss of individual freedom. For Mises, the formulation of a middle way between consumer democracies and state intervention is socially and politically hazardous, mainly due to the detrimental effects state control has on the choice and actions of the consumer citizen. State intervention, according to Mises, creates dependent beings lacking imagination and, most importantly, entrepreneurial skills. Individuals are perfectly capable of pursuing their interests without the help of the state and all economic science and activity can be stripped down to basic human action - a "praxeology" in Mises' lexicon.

As soon as we start considering contemporary forms of neoliberalism and neoliberal practices, political theorisations permeated by state phobia appear naïve and parochial. Mises' theorisation prevents us from understanding how the state coexists with the autonomy of the market and the individual pursuit of interest and freedom. In the final analysis, the issue at stake is not how to minimise the operation of the state but rather how to deploy and legitimise specific governmental actions and policies for supporting and reproducing the pivotal role of the market in all socio-political relations. Contrary to the laissez-faire economics and prevalent state phobia, Friedrich A. Hayek (2011:331) argued for a "permanent legal framework which enables the individual to plan with a degree of confidence and which reduces human uncertainty as much as possible". Hayek's references to law and human uncertainty indicate that neoliberalism should not necessarily be seen as a destructive force threatening established institutions while imposing the rule of the market. Most importantly, Hayek's argument points out to the "denaturalisation" of both markets and competition (Gertenbach 2017; Foucault, 2004). Competing in global and national markets cannot and should not be perceived as some form of a primordial act that has been tamed and distorted by state regulation but rather as a political artifice whose function is to create a specific code of conduct and then evaluate this conduct according to specific benchmarks such as economic growth and profit maximisation. 
Following the theoretical elaborations of Foucault (2004), Brown (2005) and Dardot and Laval (2013), neoliberalism should also be seen as productive in terms of establishing new social relations and new ways of living. Neoliberalism delineates competition between workers, the unemployed, policymakers and technological forces as a normal socio-political condition in which all social inequalities are legitimised on condition that the market dictates the rules of the competition. Part of neoliberalism's productive character is the transformation of the state into an ally and an enabler of market competition by designing and implementing policies aspiring to create the ideal political and economic conditions for profit maximisation. The main criticism directed towards the state is its general lack of efficiency and entrepreneurial spirit. In turn the state needs to respond to these criticisms by directing its focus from welfare to enterprise and to appear as an equal partner in the implementation of the agenda of competitiveness and economic growth. This new "'disenchanted' conception of public action" (Dardot and Laval 2013: 217) is legitimised by the state's commitment to the common good. The latter mirrors the values and aspirations of neoliberalism, of course, and it is usually understood as a series of abstract economic indices such as high productivity, low unemployment, trained and efficient labour and, ultimately, a growing economy.

11 If and when the doctrine of the competitive market fails to deliver economic growth, higher productivity and a more efficient labour force, it is because the state has not been supportive enough of corporations and is not in tune with the free-market doctrine. The discourses of technological displacement and low-skilled immigrant labour have been developed as part of a solution to the problem of low productivity and competitiveness of the UK economy. As the two case studies will demonstrate, the state is regarded as a political actor tasked with reforming and managing society and its members in order to create the optimal conditions of corporations to thrive and, by association, to contribute to the growth of the economy.

\section{Automation and Productivity: The Categorisation and Training of the Labour Force}

12 Political and economic tensions between labour and technology have been a permanent feature of capitalism. Karl Marx (2004) argued in Capital that such tensions are the direct outcome of the continuous development of the forces of production. The technological advancements of industrialisation and automation expose the contradictions between productivity and the constant fear of being excluded from the production process and between unequal distribution of wealth and belief in the legitimacy of capitalism as a particular socio-political order. A logical step into this inquiry would be to identify the workers and, more specifically, the social classes mostly affected by technological advancements. Human labour has always been under threat by industrialisation, automation and, more recently, with robotics and AI. Even though processes of technological advancement have been at the forefront of arguments about efficiency, productivity and economic growth, they have now been incorporated into debates about the future of capitalism itself. According to Streeck (2016), capitalism's existential crisis can be explained by two distinctive, yet interrelated, phenomena: first, the processes of replacing human labour are steadfast and largely unopposed; second, the target of automation has now shifted from the 
manual working class to the middle class to the defenders of an economic system based on private property, market economy and entrepreneurial activity. Robots and automation might render a significant percentage of jobs obsolete, but their sole purpose is to minimise taxation and maximise profits.

Does capitalism demarcate new battle lines between workers and robots? Is it possible for contemporary capitalism to survive without the support of wage earners? The driverless car is one of the most indicative examples for communicating both anxieties about labour displacement and a sense of optimism about a productive, growing economy. If cars can drive themselves, what will happen to professional drivers? Will they be permanently displaced by technological advancements? The UK government's 2017 Autumn Budget illustrates the need for more automation and autonomous technology in order to combat chronic low productivity. Relying on figures from the OECD, the budget states that productivity growth amongst developed economies has been at least 1 percentage point slower since 2008 than in the preceding decade. However, in the UK, the Autumn Budget points out that the slow-down has been more severe and productivity growth averages $0.1 \%$ since 2008 compared to $2.1 \%$ in the preceding decade (HM Treasury 2017: 11). One of the main arguments of the Autumn Budget (2017) is that "an economy driven by innovation will place the UK as a world leader in new technologies such as Artificial intelligence (AI), immersive technology, driverless cars, life sciences and FinTech" (HM Treasury 2017: 43). A significant part of this new technology and innovation agenda deals with what the government calls "connected and autonomous vehicles (CAVS)". The government wants to see autonomous, self-driving cars on UK roads by 2021. This ambition will come to fruition through changes in the regulatory framework for testing autonomous vehicles without human operators, and through the adjustment of present and future road networks to support these vehicles. In a subsequent interview, Philip Hammond, the Chancellor of the Exchequer, predicted that a million British workers would have to retrain and acquire a new set of professional skills to be employed in new jobs created in this new economy. "It is going to revolutionise our lives, it is going to revolutionise the way we work. And for some people this will be very challenging". ${ }^{1}$

The ambition to populate roads with driverless cars extends to the transportation of goods. While corporations such as Google and Toyota have been active in the development of cars which will revolutionise work and everyday life, lorry manufacturers are developing similar technologies aiming at minimising costs in transporting goods. "Labour accounts for up to 45 per cent of total road freight cost" (International Transport Forum 2017: 9) and driverless lorries will redefine profit margins and ultimately redefine the rules of competition. As a result, up to 4.4 million of the 6.4 million professional trucker jobs in the US and Europe could be eliminated by autonomous technology (ibid.: 7). Even though the report asserts the resilience and adaptability of the work force under consideration, it concludes that their relatively low education level would be almost prohibitive for acquiring new and diverse training skills and knowledge.

The links between automation, education and labour displacement are further explored in a report published by PricewaterhouseCoopers (Berriman 2017). The report emphasises the potential loss of jobs due to accelerated automation and predicts that $30 \%$ of jobs in the UK could potentially be at high risk by the early 2030s, compared with $38 \%$ in the US, $35 \%$ in Germany and $21 \%$ in Japan (Berriman 2017). According to 
the report, employment sectors such as "transport and storage", "manufacturing" and "wholesale and retail" are more exposed to the risks of automation and subsequent loss of jobs, whereas "health and social care" appears to be immune to automation and robotics. The figures presented by the report largely depend on the educational level of workers. Workers with undergraduate or higher degrees will be better equipped to adapt to a new economy and labour market, while for workers with GCSEs or no formal qualifications automation presents a clear threat to their employment prospects. The report argues that labour displacement can be managed by the proliferation of new jobs created by new technologies and by (re)training initiatives for workers in order to acquire the right skills for a challenging new labour market.

Governmental intervention in the domains of education and vocational training are at the forefront of the report of the Future of Work Commission (2017). Falling real wages and increasing inequality are considered by the report to be some of the most significant by-products of automation. On the whole, the report welcomes the new technological shift towards automation, robotics and AI due to its potential to decrease working hours, increase productivity and contribute to higher standards of living. Such potential can only be realised with policy intervention in the areas of "good work"; "skills for the future"; "innovation"; "corporate governance"; "labour rights"; and "ethics". The report advocates a stronger and more active role for the state in the new economy in order to assess the quality of the work that workers are engaged with, and the equal distribution of wealth. Lifelong learning and the establishment of education trusts in conjunction with new tax rates for incentivising business to invest more in their workforce will position the state as an active actor in the management of the new economy.

Skills, training and education, innovation and investment appear to be constant themes in the analysis of technological displacement. The "Future of Jobs" report published by the World Economic Forum does not necessarily diverge from these themes, yet introduces the issue of diversity as another defence strategy for avoiding skills shortage in an economy dominated by automation. In what the report refers to as the "Fourth Industrial Revolution", human resources departments will have to be able to analyse skills gaps and determine how to align their workforce to meet present and future challenges (Gray 2016). The report states that diversity in the workplace will increase in significance as corporations and smaller businesses will have to recruit workers from across the world to fill gaps in skills specific to technological innovation and automation.

Overall, the above-mentioned reports shift the focus from the integration of workers as a collective into a new economic and social order, to a "project of self-realisation" (Boltanski and Chiapello 2007: 217) by establishing links between performance, knowledge and the ability to remain employable in the new, and more demanding, corporate environment. As a result, the flexibility that all reports implicitly or explicitly demand through retraining and acquiring new skills transfers the uncertainty of insecure employment from the corporation to the actual workforce. Lack of access to retraining programmes or the unwillingness of corporations to provide such programmes will inevitably lead to the casualisation of a big proportion of the current labour force. The new technological displacement is presented by these reports as an unstoppable force whose missions are primarily to address low productivity and ,secondly, to categorise the current and future labour force according 
to the binary oppositions of competent and incompetent, trained and untrained, educated and uneducated, flexible and inflexible. The overwhelming emphasis on training and future investment also indicates the selection process of corporations and other businesses regarding their labour force. Access to training will be offered to those "whose disposition is deemed sufficiently promising to justify the investment" (Boltanski and Chiapello 2007: 237). Once retrained, workers need to fulfil the promise of a productive, automated and growing economy, and will be indebted to the corporation for maintaining their employment status. The anxiety over employment and skills is designed to prevent workers from challenging the structures of the new economy either as individuals or as part of a union.

As the alliance between state and corporation for the sustainability of the competitive labour market depends on the marginalisation of workers both as productive force and as active agents capable of challenging economic norms and structures, new contested sites emerge around the issues of workers' unionisation, working hours, income and taxation. Despite the fact that trade union membership is at an all-time low (Department for Business, Energy and Industrial Strategy, 2018), precarious work and social insecurity have generated action by smaller unions such as the Independent Workers Union (IWGB) and the Industrial Workers of the World (IWW), and in collaboration with the Trades Union Congress (TUC) have enabled precarious workers at the intersections of automation and self-employment to share their experiences and take part in legal battles over employment status and bargaining powers (Trades Union Congress 2017; Chakelian 2018). By acknowledging the automation of work as an irreversible process, unions demand the spreading of the benefits of new technologies. Secure employment, a reduced number of working hours and the introduction of Universal Basic Income (UBI) as a basic wage paid to every citizen constitute a new set of demands for a new type of society. Even though the description and implementation of UBI are subject to theoretical and policy debates (Srnicek and Williams 2016) unions and supportive policy-makers hope to set in motion a radical reconsideration of policy over the categorisation of citizens into employed and unemployed, skilled or unskilled. Due to the shrinking workforce, the implementation of UBI will not necessarily rely on income tax but on the actual taxation of the agents of automation, namely corporations and their technological infrastructures.

\section{The Use of Immigrant Labour}

20 Arguments about productivity and economic growth are not limited to the discourse of automation and technological displacement. Rather, they extend to the mobility of labour and immigrant labour in particular. Immigration has either been articulated by media and political discourses as labour mobility that needs to be assessed according to a cost-benefit analysis, or as a socio-cultural process capable of re-defining the limits of national identity, belonging, and of dominant cultural patterns. More specifically, in order for immigration to be considered positive, the input of immigrant workers needs to surpass their impact on public services such as housing, health and education. However, for the Leave campaign and its affiliated media, the impact of immigration on the dominant definitions of national culture and social cohesion became a powerful persuasive tool for the lead-up to the UK's decision to disentangle itself from the structures, laws and policies of the EU (Pencheva and Maronitis 2018). In anticipation of 
the communication of a concise post-Brexit immigration policy, the Migration Advisory Committee (2018) published a report outlining a socio-economic structure that supports economic growth while recognising the predominantly Eurosceptic electorate's anxieties over the control of national borders, access to housing, employment and welfare. The report argues for the need to offer visas to immigrants in a tiered system based on skills and income in proportion to their contribution to the UK economy (Financial Times 2018). However, such suggestions have been rebuked by business who demand access to a larger pool of unskilled and low-skilled workers to fill in vacancies in the construction, hospitality and haulage sectors of the economy. In principle, as David Goodhart (2018) suggests in the Public Policy Exchange report on post-Brexit immigration policy, employers could attract workers from the local and national labour market if they were willing to increase salaries and improve working conditions. This would result in higher prices for products and services. Eventually, the economy's competitiveness would be compromised. Present and future immigration policies will have to reflect public anxieties generated by media discourses and political rhetoric about the impact of immigration on cohesion, identity and public services and at the same time to address the needs of the economy in terms of skills, salaries, and overall number of the working population (Maronitis 2016).

The prospect of a new immigration policy framework that would enable the government to refuse EU immigrants the right to work in the UK, as well as forcing employers to recruit British citizens to perform jobs previously considered as unattractive, has led a number of thinktanks, political and business figures to defend current levels of immigrant labour solely for maintaining economic growth and existing standards of living. The National Institute of Economic and Social Research (NIESR) differentiates between "middle range" and "hard" Brexit and provides an assessment with respect to immigration and economic growth (Rolfe and HudsonSharp 2016). In the "middle range" scenario where immigration falls by as much as 91,000 a year, the GDP per head will be $3.4 \%$ lower than it would have been by 2030 . In the "hard" Brexit scenario, the institute estimates that if immigration were cut by 150,000 a year then the annual GDP would be lower 5.4\%. According to the NIESR, both moderate and sharp cuts in immigration would not necessarily have a positive impact on the wages of British workers employed in the most immigration-dependent sectors of the UK economy, namely construction, hospitality, retail and food processing. In particular, the "middle range" scenario would only contribute to a $0.5 \%$ rise in wages whereas the "hard" Brexit scenario would increase wages by $0.82 \%$ (Rolfe and HudsonSharp 2016).

The NIESR continues its investigation into the impact of Brexit on immigration and employment by illustrating the employers' concerns over possible free movement restrictions. The report indicates that most employers believe that Brexit and restrictions of free movement of labour would exacerbate their chronic recruitment difficulties and labour shortages. According to the report, these concerns are not only about the quantity of workers but also about the quality of work they perform.

Everywhere you go in the leisure sector you will see lots of people from Eastern Europe. And it is not because they are any cheaper because we have the minimum wage and we have the national living wage. But they deliver a far better experience (Rolfe 2016: 8). 

vegetable farms in the UK were in need of thousands of immigrant workers and as a result produce were left to rot in the fields. According to survey data from the National Farmers Union, more than 4,300 vacancies were left unfilled, which approximately covers $50 \%$ of the horticultural labour market. The survey points out that $99 \%$ of the seasonal workers employed in the sector are from Eastern Europe and 0.6\% from the UK. Farmers in the UK claim that the vote to leave the EU has created the perception among foreign workers that the country is xenophobic and unwelcoming. The Secretary of State for Environment, Food and Rural Affairs and a prominent political figure in the campaign to leave the $\mathrm{EU}$, addressed the concerns of farmers by insisting workers from the EU would still be able to work in UK farms, but they would have to get registered and sign temporary contracts in order to "augment" the horticultural labour force post-Brexit (Ferguson 2017). For the Secretary of State, one way to reconcile popular demands for control of immigration with economic growth would be to import seasonal workers according to specific demands in the labour market and effectively reinstate the Seasonal Agricultural Workers Scheme (SAWS). He explains that the current limited mobility of immigrant workers is not due to the negative perceptions of the UK as racist, but due to the growing economies of their countries of origin. "It's already the case that the supply of labour from EU27 countries is diminishing as their economies recover and grow. So, in the future, we will need to look further afield" (Hughes and Daneshkhu 2018).

Yet, a survey conducted by the Royal Association of British Dairy Farmers (2017) has revealed that EU migrant workers are neither employed on a temporary basis nor are they perceived as transient workers. They are usually employed and perceived by their employers as permanent and integral members of the workforce. As in the leisure and hospitality sectors, employers in the farming and horticultural sectors are reluctant to employ and invest in the training of workers from the local and national labour markets. Preference for immigrant over domestic workers is usually explained by the willingness of the former to work more hours, positively respond to flexible working schedules, and live in the accommodation spaces provided by farms.

Reports on the state of the economy during and after the Brexit negotiations and demands from professional bodies for sustaining the current levels of immigrant labour in the UK illustrate the importance of immigration and of immigrant workers. Following Abdelmalek Sayad's remarks on the social implications of immigration, it can be argued that immigrant workers are only accepted as long as they are defined by the work they perform. For Sayad, "the immigrant is only a body" (2007: 213) that is required to perform certain tasks and subsequently present her/himself as labour power. Outside the environments in which immigrants work and live, they are considered "minors" who need to be taught the local customs and the demands of the host economy and society. Sayad substantiates his argument on the singular perception of the immigrant as a working body by distinguishing between body and head, between working and thinking. Here, the implicit references to Aristotle's "use of the body" for defining the nature of the slave are too strong to ignore. Aristotle defines the slave "as the human being whose work consists only in the use of the body" (Agamben 2016: 5).

Angles, 8 | 2019 
Agamben argues that Aristotle does not necessarily deny the slave's human nature but insists that the work performed by the slave is not human work. The simultaneous exclusion and inclusion from humanity provides the slave with a special status that can be explained as an act of legislation and of necessity. Agamben points out that even though the slave is excluded from political life, his actual presence is an integral part of it. "The slave in fact represents a not properly human life that renders possible for others the bios politicos, that is to say, the truly human life" (Agamben, 2016: 20).

Agamben's reading of Aristotle enables us to perceive the socio-political exclusion of certain workers as a necessary condition for flourishing economies beyond the chronological confines of antiquity. From Hegel to Keynes and Beveridge, the presence of disposable, unskilled labour with no rights and access to welfare, also known as the "rabble", is not an historical anomaly that has been or will be rectified by civil society, but rather a product of civil society's unresolved contradiction between freedom and deprivation (Mann 2017). For Beveridge, this contradiction would dissolve with the introduction of the welfare state and the subsequent re-understanding of civil society's purpose: "Whatever the bearing of full employment upon industrial discipline one thing is clear. A civilised community must find alternatives to starvation for preservation of industrial discipline and efficiency" (Beveridge 1944: 300).

While it would be extreme and controversial to draw parallels between the slave of the Ancient Greek city-states and the low-skilled immigrant of the UK, it is worth noting that the marginalisation of workers and, in particular, the permanent otherness of immigrants, have been historically beneficial to national economies for growth and productivity. Low-skilled immigrant workers embody a cultural, ethnic and economic otherness that determines their position in economy and society. They come from poorer countries, underdeveloped economies and are part of different historical processes, which are sometimes incompatible with the host country's social and political order. Up to a certain extent, the otherness and incompatibility that immigrants embody are desirable qualities for the regulation of their mobility and control of their rights. They find themselves at the bottom of the social and political order, due to their perception by employers and policymakers as convenient and advantageous work accessories. The attempt of the UK's Conservative government to tame anti-immigration sentiments with plans to prioritise the inflow of high-skilled over low-skilled immigrants has been refuted by businesses in agriculture, farming, hospitality and leisure businesses. Minimum wages, the willingness to do jobs British citizens are unwilling to do and objective difficulties to form or be part of workers' unions constitute low-skilled immigrant workers as vital components for the country's economic growth and productivity.

The route to economic growth and productivity via the exploitation of low-skilled immigrant workers has been contested by the formation and subsequent action of new trade unions such as United Voices of the World and Independent Workers Union of Great Britain (2018). These unions address the pervasive precarious working conditions in hospitality, care and domestic services and campaign for minimum and living wages, dignified and safe conditions, and access to legal representation for all low-skilled immigrant workers. According to these unions, such actions aim at the integration of low-paid immigrant workers in a labour market in which standard rules, regulations and rights should be applied to all workers irrespectively of their ethnicity, qualifications and type of work. 


\section{Homo Economicus: Constructing and Governing the Subject of Neoliberalism}

The discourses of technological displacement and cheap, low-skilled immigrant labour normalise uncertainty and insecurity for the working population. On the one hand, there are people in work who have to be flexible, responsive and always willing to be retrained in order to be employable. On the other hand, there are people who are willing to work in jobs which are considered to be undesirable, low-paid and less secure. The uncertainty and fear communicated by the reports, policies and statements are by no means an indication of a political and economic system in disarray. In fact, fear and uncertainty are part of the motivational strategy ingrained in the "new spirit of capitalism" (Boltanski and Chiapello 2007).

31 Fear and uncertainty as well as the categorisation of labour in relation to training programmes, exposure to technological advancements and immigration flows indicate that neoliberalism is much more than an economic system. Foucault argued that neoliberalism is an all-encompassing political system in which new subjectivities emerge (2004). The ways these subjectivities conduct themselves in competitive environments, and at the same time are being evaluated by the rules and standards of competition, reveal the political character and aspirations of neoliberalism. For Foucault, neoliberalism is a political rationality that aspires to produce a permanent consensus amongst all those who operate within its confines. Industrialists, manual workers, employees, business executives, politicians, policymakers, and law and order enforcement need to operate and conduct themselves according to the principles of competition and of the free market. This consensus requires and at the same time manifests itself with the existence of a collective subject that transcends class and status, capable of navigating under insecure and challenging political and economic conditions. This subject is predominantly defined by the dominance of the market and has been known historically as homo œeconomicus. From Adam Smith and Adam Ferguson to Ludwig von Mises, Friedrich Hayek and Milton Friedman, homo œconomicus has been the defining subject of both liberalism and neoliberalism. However, for Foucault, there is a noticeable change in the understanding and actions of homo ceconomicus. In liberalism, homo ceconomicus was understood as "the partner of exchange and the theory of utility based on a problematic of needs" (Foucault 2004: 225). According to this conception, the market serves as a social space where participants offer what they have, in exchange for what they need. In neoliberalism, the market as a place of exchange is transformed into a place of competition where the participants are not necessarily interested in exchange, but instead in "investing" in themselves as both producers and consumers (Foucault 2004: 226).

At this point, it has to be noted that the neoliberal homo œconomicus is not a subject constructed and understood within the limitations of structuralism. Following the theoretical elaborations of Michel Wieviorka (2012) and Alain Touraine (2000, 2010), it can be argued that homo ceconomicus is an achievement and a product of constant struggle against institutions which seek to regulate the market and personal interest. However, homo œconomicus needs to be reconsidered across the multiple manifestations of neoliberalism and the relationship the latter establishes with other social and political spheres such as technology and immigration. Wendy Brown suggests that 
Foucault's conceptualisation of the neoliberal subject needs to be updated in order to capture new power dynamics between the individual, employment and the market.

Put it differently, rather than each individual pursuing his or her own interest unwittingly generating collective benefit, today, it is the project of macro-economic growth and credit enhancement to which neoliberal individuals are tethered and with which their existence as human capital must align if they are to thrive (Brown 2015: 84).

Neoliberalism demands from economic actors to trade off their rights and liberties for access to, and participation in, the market. At the same time, the state's input is not limited to the design and implementation of a legal framework that allows the expansion of the market in all spheres of social and political life but rather extends to the minimisation and, if possible, the elimination of all opposing forces to such expansion (Streeck 2014). In addition to the transition from liberalism to neoliberalism identified by Foucault, Brown highlights a new transition in the history of neoliberal subjectivity. Homo ceconomicus is transformed from a subject attached to power, to a subject existing in precarity: job insecurity and labour flexibility; private and national debt; austerity and fiscal consolidation. For Brown, the raison d'être of the contemporary homo ceconomicus is not necessarily self-interest but survival and sacrifice in a political and economic order that disregards notions of social security and employment stability.

The present employment conditions, in conjunction with anxieties about technological displacement, low productivity and the need for a flexible labour force with minimal rights constitute homo œconomicus as the defining collective subject of neoliberalism's strength and fragility. The indiscriminate exposure to precarious living conditions functions as a disciplinary mechanism for all those partaking in the competitive market economy delineated by neoliberalism. The way the competitive labour market affects the existing and aspiring labour force creates the perception of permanent employment as a privilege that needs to be preserved, regardless of the cost.

Is it possible to speak of a social class based on the common experience of competition and precarious working conditions? Is it possible to speak of a social class created in the ruins of the state as the central organising principle of both the economy and society (Hardt and Negri 2001; Virno 2004)? At this stage, it is important to underscore the critical role inequality plays in the neoliberal order. The competitive labour market does not aspire to the creation of a level playing field of insecurity and exploitation. As Hayek notes, "people in general do not regard mechanical equality of this kind as desirable" (2003: 65), because it restrains the individual's willingness to perform. With this in mind, the experience of precarious working conditions and social insecurity needs to vary in order to discourage the formation of a social class challenging the neoliberal order and also to encourage individuals to increase their performance in order to remain in employment. Compliance with the political system no longer depends on a strong state capable of protecting its subjects from lawlessness, insecurity and external threats. Instead, the new art of governance involves the precarisation of individuals and their subsequent hierarchy and relations. In the absence of social protection, precarisation needs to be regulated in order to remain politically legitimate and, more importantly, its "extent must not pass a certain threshold such that it seriously endangers the existing order: in particular, it must not lead up to insurrection. Managing this threshold is what makes up the art of governing today" (Lorey 2015: 2). 
Precarisation, then, becomes not only the main governmental device of neoliberalism but also an effective medium for understanding social order and hierarchies between precarious workers. The normalisation of precarisation indicates that British society is quintessentially governed through insecurity. The art of neoliberal governance consists in maintaining a balance between the maximum precarisation of working conditions with the minimum safeguarding provided by the state, such as (re)training schemes and controlled flows of immigrant labour. Whereas precarisation refers to governance, precarity refers to a specific order that groups individuals according to their exposure to insecurity, and at the same time determines their rightful compensation. This is the moment of the fragmentation of the neoliberal subject homo œeconomicus - a fragmentation that occurs along the dividing lines of national and foreigner, domestic and immigrant. Even though higher productivity and economic growth targets remain elusive, yet of paramount importance, the state still retains the obligation to discriminate between domestic and foreign workers. The dynamic relationship between employment and unemployment, security and insecurity becomes an integral part of the art of neoliberal governance. Governmental precarisation aspires to create substandard working environments for immigrant workers with minimal rights and lower salaries in order to maintain a sense of security and certainty for domestic workers and ultimately manage the acceptable threshold of precarisation in society.

\section{Conclusion}

The discourses of technological displacement and low-skilled immigrant labour construct a narrative in which competition, precarious employment and insecurity are normalised. This narrative is produced, disseminated and controlled by businesses and the government, and occasionally contested by trade unions and individual workers. Despite differences and conflicting interests, the government and corporations are able to defend and promote the values and ethos of neoliberalism, as manifested in the competitive labour market, by pointing out to the necessity of economic growth, everhigher productivity, and the country's ability to compete in the global economy. This article demonstrates that the construction of this narrative is based on two developments. Firstly, those two discourses aim at the de-politicisation of the economy and of the labour market, in particular. Economic growth, productivity and competitiveness appear as objectives that need to be achieved regardless of political and ideological inclinations. To that effect, technological displacement and workers with minimal rights appear as a necessary trade-off. Secondly, the two discourses under consideration formulate a new collective subjectivity within the theoretical and empirical frameworks of neoliberalism. Individual workers are deprived of their collective defences, and their sole aim is to survive in the competitive labour market by re-training and accepting lower wages, flexible working hours and substandard working conditions.

In order to politicise the labour market, the article juxtaposes the discourses of technological displacement and labour mobility with union responses, and establishes a theoretical and empirical connection between precarisation and neoliberal governance. By situating homo œeconomicus as the defining subject of the competitive labour market, the article argues that technological automation and immigration are not inherently progressive, instead, their character depends on the political organisational framework 
of the economy. Neoliberal governance asserts its dominance through the fragmentation and further categorisation of homo economicus according to nationality, ethnicity, levels of precarisation and state compensation. The contemporary labour market as an empirical manifestation of neoliberalism becomes an art of governance by simultaneously uniting and fragmenting its collective subject through the process of precarisation.

\section{BIBLIOGRAPHY}

Agamben, Giorgio. The Use of Bodies. Stanford: Stanford UP, 2015.

Berardi, Franco "Bifo". Futurability: The Age of Impotence and the Horizon of Possibility. London: Verso, 2017.

Beveridge, William. Full Employment in a Free Society. London: Allen and Unwin, 1944.

Berriman, Andrew. "Will robots steal our jobs? The potential impact of automation on the UK and other major economies”. In PricewaterhouseCoopers. UK Economic Outlook 2017.

PricewaterhouseCoopers, 2017. https://www.pwc.co.uk/economic-services/ukeo/pwcukeosection-4-automation-march-2017-v2.pdf.

Boltanski, Luc and Eve Chiapello. The New Spirit of Capitalism. London: Verso, 2007.

Brown, Wendy. Undoing the Demos: Neoliberalism's Stealth Revolution. Brooklyn: Zone Books, 2015.

Chakelian, Annosh. ““'Slaveroo": How Riders are standing up to Uber, Deliveroo and the gig economy". New Statesman, 24 September 2018. https://www.newstatesman.com/politics/uk/ 2018/09/slaveroo-how-riders-are-standing-uber-deliveroo-and-gig-economy

Dardot, Pierre and Christian Laval. The New Way of the World: On Neoliberal Society. London: Verso, 2014.

Department for Business, Energy and Industrial Policy. “Trade Union Membership 2017: Statistical Bulletin”. Department for Business, Energy and Industrial Policy, 2018. https:// assets.publishing.service.gov.uk/government/uploads/system/uploads/attachment_data/file/ 712543/TU_membership_bulletin.pdf.

Ferguson, Kate. "Low skilled EU workers will still be allowed to come to UK for 'seasonal' jobs post-Brexit, Gove says”. Daily Mail, 2 October 2017. https://www.dailymail.co.uk/news/ article-4941378/Gove-Low-skilled-EU-workers-come-Uk-post-Brexit.html

Financial Times. "A dose of common sense on UK immigration”. Financial Times, 19 September 2018.

Foucault, Michel. The Birth of Biopolitics: Lectures at the Collège de France. Michel Senellart (ed), Graham Burchell (trans.). New York: Picador, 2004.

Future of Work Commission. Report of the Future of Work Commission. West Bromwich: Terry Duffy House, 2017. https://d3n8a8pro7vhmx.cloudfront.net/campaigncountdown/pages/1052/ attachments/original/1512946196/Future_of_Work_Commission_Report__December_2017.pdf? 1512946196. 
Gertenbach, Lars. "Economic Order and Political Intervention: Michel Foucault on Ordoliberalism and its Governmental Rationality". In Thomas Biebricher and Frieder Vogelmann (eds). The Birth of Austerity: German Ordoliberalism and Contemporary Neoliberalism. London and New York: Rowman and Litttlefield, 2017.

Goodhart, David. "Immigration After Brexit: What should post-Brexit immigration policy look like?”. Policy Exchange, 2018. https://policyexchange.org.uk/wp-content/uploads/2018/01/ Immigration-after-Brexit.pdf.

Gray, Alex. “5 Million jobs to be lost by 2020”. World Economic Forum, 2016. https:// www.weforum.org/agenda/2016/01/5-million-jobs-to-be-lost-by-2020/.

Hardt, Michael and Antonio Negri. Empire. Cambridge, Massachusetts: Harvard UP, 2001.

Hayek, Friedrich A. The Constitution of Liberty. Chicago: U. of Chicago P., 2011.

Hayek, Friedrich A. The Road to Serfdom. London: Institute of Economic Affairs, 2003.

HM Treasury. Autumn Budget 2017. London: HMSO, 2017. https://assets.publishing.service.gov.uk/ government/uploads/system/uploads/attachment_data/file/661480/ autumn_budget_2017_web.pdf.

Hughes, Laura and Shari Daneshkhu, "Gove calls for post-Brexit seasonal workers scheme for farms". Financial Times, 20 February 2018.

Independent Workers Union of Great Britain. "Public Policy”. Independent Workers Union of Great Britain, 2018. https://iwgb.org.uk/page/about/public-policy.

International Transport Federation. "Managing the Transition to Driverless Road Freight Transport”. International Transport Federation, 2017. https://www.itf-oecd.org/sites/default/ files/docs/managing-transition-driverless-road-freight-transport.pdf.

Jessop, Bob. "Neoliberalism". In George Ritzer (ed.). The Wiley-Blackwell Encyclopedia of Globalization. Vol. 2. West Sussex: Wiley-Blackwell, 2012: 1513-21.

Lorey, Isabell. State of Insecurity: Government of the Precarious. London: Verso, 2015.

Mann, Geoff. In the Long Run We Are All Dead: Keynesianism, Political Economy and Revolution. London: Verso, 2016.

Maronitis, Kostas. Postnationalism and the Challenges to European Integration in Greece: The Transformative Power of Immigration. Basingstoke: Palgrave-Macmillan, 2016.

Marx, Karl. Capital: A Critique of Political Economy. Vol. 1. London: Penguin, 2004.

Migration Advisory Committee. “EEA Migration in the UK: Final Report”. Migration Advisory Committee, 2018. https://assets.publishing.service.gov.uk/government/uploads/system/ uploads/attachment_data/file/741926/Final_EEA_report.PDF.

National Farmers Union. "Drop in seasonal workers leaves some farmers critically short". National Farmers Union, 2017. https://www.nfuonline.com/news/latest-news/drop-in-seasonalworkers-leaves-some-farms-critically-short/.

Pencheva, Denny and Kostas Maronitis. "Fetishizing Sovereignty in the Remain and Leave Campaigns”. European Politics and Culture, 19:5, 2018: 526-539. DOI: 10.1080/23745118.2018.1468948

Rolfe, Heather. "Employers' responses to Brexit: The perspective of employers in low skilled sectors". National Institute of Economic and Social Research, 2016. https://www.niesr.ac.uk/ sites/default/files/publications/Employers\%20and\%20Brexit\%20final.pdf. 
Rolfe, Heather and Nathan Hudson-Sharpe. "The Impact of Free Movement on the Labour Market: Cases Studies of Hospitality, Food processing and Construction". National Institute of Economic and Social Research, 2016. https://www.niesr.ac.uk/sites/default/files/publications/ Free\%20movement\%20-\%20Final\%20report.pdf.

Sayad, Abdelmalek. The Suffering of the Immigrant. Cambridge: Polity Press, 2007.

Srnicek, Nick and Alex Williams. Inventing the Future: Postcapitalism and a World Without Work. London: Verso, 2016.

Streeck, Wolfgang. Buying Time: The Delayed Crisis of Democratic Capitalism. London: Verso, 2014.

Streeck, Wolfgang. How Will Capitalism End? Essays on a Failing System. London: Verso, 2016.

The Royal Association of British Dairy Farmers. "The importance of European Union labour to the UK dairy sector”. The Royal Association of British Dairy Farmers, 2017. https:// static1.squarespace.com/static/55115f04e4b0f4baa9ed963c/t/59d37db190badee58a10af3c/ 1507032499029/Report+on+importance+of+EU+labour+to+UK+dairy+sector.pdf.

Trades Union Congress. “The Gig is Up: Trade Unions Tackling Insecure Work”. Trades Union Congress, 2017. https://www.tuc.org.uk/sites/default/files/the-gig-is-up.pdf

Touraine, Alain. Can We Live Together? Equality and Difference. Stanford: Stanford UP, 2000.

Touraine, Alain. "Sociology Upside Down: From Systems to Subjects". New Cultural Frontiers 1(1), 2010: 4-15.

United Voices of the World. "What We Do". United Voices of the World, 2018. https:// www.uvwunion.org.uk/what-we-do/

Virno, Paolo. A Grammar of the Multitude. Los Angeles and New York: Semiotext(e), 2004.

Von Mises, Ludwig. Human Action: A Treatise on Economics. Alabama: Ludwig Von Mises Institute, 1998.

Wieviorka, Michel. Evil. Cambridge: Polity Press, 2012.

\section{NOTES}

1. “Today Programme”. BBC Radio 4, 23 November 2017.

\section{ABSTRACTS}

This article identifies the points of divergence and convergence between the discourses of technological displacement and low-skilled immigrant labour and argues for the understanding of a new model of neoliberal governance. New technologies, new managerial and organisational strategies, and new models of exploitation emerged in the aftermath of the 2008 financial crisis in the UK. What are the main features of this crisis? The article points to two different yet interconnected processes. First, due to demands for higher productivity and economic growth the advent of automation, robotics and AI is presented as an irreversible process capable of 
producing a new corporate environment in which low labour costs and efficiency co-exist with massive job losses, waning of workers' collective defences and re-training programmes. Second, for all the increasing popularity of protectionist politics and of demands for tight immigration controls the need for low paid and low-skilled immigrant labour across several sectors of the UK economy remains unchanged. Demands for economic growth render the presence of low-skilled immigrants necessary as long as they are subjected to the minimum political, economic and social provisions such as wages, political participation and mobility. As a result, low-skilled immigrants must exist within a political and economic environment in which they are perceived as useful and at times essential accessories for sustaining economic growth and public services. The concepts of precarisation and precarity provide a useful insight into the underlying logic that connects and differentiates those two discourses. In particular, precarisation becomes at once the dominant mode of governing the population and the most effective means for capital accumulation. In contradistinction to old understandings of government that demanded political compliance in exchange for the promise of social protection, the neoliberal process of precarisation increases instability and provides the minimum of insurance. Precarisation is not limited to employment but more generally to the formulation of homo œconomicus as a collective neoliberal subject living in fear and uncertainty. Precarity, on the other hand, designates a sense of hierarchy amongst insecure workforce and the compensations they receive. The article concludes by arguing that the dividing lines between national and foreigner, domestic and immigrant, become integral notions of neoliberal governance for differentiating between precarious groups and maintaining order in contemporary capitalism.

Cet article identifie les points de divergence et de convergence entre les discours portant respectivement sur l'automatisation et sur la main d'œuvre immigrée peu qualifiée, pour défendre une compréhension nouvelle du modèle de gouvernance néolibéral. De nouvelles technologies, de nouvelles stratégies managériales et organisationnelles et de nouveaux modèles d'exploitation ont émergé à la suite de la crise financière de 2008 au Royaume-Uni. Quels sont les aspects principaux de cette crise ? L'article met en exergue deux processus, distincts mais reliés. Tout d'abord, en raison des exigences croissantes en termes de productivité et de croissance économique, l'avènement de l'automatisation, de la robotique et de l'intelligence artificielle est présenté comme une processus irréversible susceptible de produire un nouvel environnement professionnel, dans lequel la réduction du coût du travail et les gains en efficacité sont concomitants de suppressions massives d'emplois, d'un affaiblissement des protections collectives dont bénéficient les travailleurs et de programmes de requalification professionnelle. Deuxièmement, en dépit de la popularité croissante des politiques protectionnistes et des appels à un contrôle plus strict de l'immigration, les besoins de plusieurs secteurs de l'économie britannique en matière de main d'œuvre immigrée peu qualifiée demeurent inchangés. Les exigences en termes de croissance économique rendent la présence de ces immigrants peu qualifiés nécessaire, pour autant qu'ils bénéficient de droits politiques, économiques et sociaux minimaux - salaires, participation politique et mobilité. Il en résulte que les immigrants peu qualifiés doivent exister dans un environnement politique et économique dans lequel ils sont perçus comme des rouages utiles - parfois essentiels - de la croissance économique et des services publics. Les concepts de précarisation et de précarité fournissent un éclairage précieux sur la logique sous-jacente qui relie ces deux discours tout en les différenciant. La précarisation est devenue le mode dominant de gouvernement de la population et le moyen le plus efficace de permettre l'accumulation du capital. À rebours des conceptions anciennes du gouvernement, dans lesquelles l'obéissance politique était échangée contre la promesse d'une protection sociale, le processus néolibéral de précarisation accroît l'instabilité et ne fournit qu'un minimum de protection. La précarisation n'est pas limitée à l'emploi, mais s'inscrit dans la formulation plus large de l'homo ceconomicus comme sujet collectif néolibéral vivant dans la peur et d'incertitude. 
La précarité, quant à elle, désigne la hiérarchie établie au sein des travailleurs vivant dans l'insécurité, et les formes de compensation qu'ils en retirent. L'article conclut en affirmant que les lignes de partage entre le national et l'étranger, le natif et l'immigrant, font partie intégrante d'une gouvernance néolibérale qui opère des distinctions entre groupes précaires pour maintenir l'ordre au sein du capitalisme contemporain.

\section{INDEX}

Mots-clés: automatisation, immigration, néolibéralisme, précarisation, homo œconomicus, gouvernance

Keywords: technological displacement, immigration, neoliberalism, precarisation, homo œconomicus, governance

\section{AUTHOR}

\section{KOSTAS MARONITIS}

Kostas Maronitis is Lecturer in Politics and International Relations at Leeds Trinity University. His research on immigration, human rights, political activism and citizenship has been published by European Politics and Society, Cultural Politics, and the New Statesman. Kostas Maronitis is the author of the book Postnationalism and the Challenges to European Integration in Greece: The Transformative Power of Immigration (2017) published by Palgrave Macmillan. Contact: k.maronitis[at]leedstrinity.ac.uk 